\title{
PHYSICAL AND CHEMICAL PROPERTIES OF ORGANIC MINERAL ADDITIVE FOR RUMINANT THROUGH BIOLOGICALLY INCORPORATED BY SACCHAROMYCES CEREVISIAE IN DIFERENCE SUBSTRATES
}

\author{
SIFAT FISIK DAN KIMIA DARI ADITIF MINERAL ORGANIK UNTUK TERNAK \\ HASIL FERMENTASI SACCHAROMYCES CEREVISIAE PADA SUBSTRAT YANG \\ BERBEDA
}

\author{
Ahmad Sofyan ${ }^{1}$, Hendra Herdian ${ }^{1}$, Awistaros Angger Sakti ${ }^{1}$, Gumilang Khairulli ${ }^{2}$ and \\ Anuraga Jayanegara ${ }^{2}$ \\ ${ }^{1}$ Division of Feed and Animal Nutrition, \\ Research Unit for Processes Development and Chemical Engineering (BPPTK), \\ Indonesian Institute of Sciences (LIPI), \\ J1. Jogja-Wonosari Km. 31.5, Gading, Playen, Gunungkidul, D.I. Yogyakarta 55861 \\ ${ }^{2}$ Department of Animal Nutrition and Feed Technology, Faculty of Animal Sciences, \\ Bogor Agricultural University (IPB), \\ Jl. Agatis, Kampus IPB Darmaga Bogor 16680 \\ *E-mail: sofyan_lipi@yahoo.co.id
}

Diterima : 21 Agustus 2015, Revisi : 16 September 2015, Disetujui : 15 Oktober 2015

\begin{abstract}
This research was conducted to evaluate physical and chemical properties of organic mineral additive incorporated by Saccharomyces cerevisiae which was cultivated on different growth media consisted of cassava flour and rice bran, respectively. Treatment was arranged on completely randomized design consisted of rice bran without inoculants ( $\mathrm{RBo})$, rice bran with inoculants $(\mathrm{RBi})$, cassava flour without inoculants ( $\mathrm{CFo}$ ), cassava flour with inoculants (CFi). Substrates were fortified by microminerals contained of $\mathrm{Cu}(100 \mathrm{ppm}), \mathrm{Mn}$ (100 ppm), Zn (100 ppm), I (10 ppm), Fe (2.5 ppm) and Co $(2 \mathrm{ppm})$. Inoculation of $S$. cerevisiae could reduce fungal contamination. Physical characteristic of cassava flour was better in flavour and texture than rice bran in which tends to rancidity. Nutrients composition was similar in cassava and rice bran however crude fibre content in rice bran tends to be higher after fermentation. Mineral content ( $\mathrm{Zn}$ and $\mathrm{Fe}$ ) relatively decreased and in substrate supplemented by inoculant and rice bran had higher than cassava. In summary, micromineral was incorporated in cassava flour with inoculated $\mathrm{S}$. cerevisiae had better than rice bran.
\end{abstract}

Keywords: Organic mineral, cassava flour meal, S. cerevisiae, rice bran, ruminant.

\begin{abstract}
ABSTRAK
Penelitian dilakukan untuk mengevaluasi sifat fisik dan kimia aditif mineral organik untuk ternak hasil fermentasi Saccharomyces cerevisiae pada media tumbuh masing-masing mengandung tepung singkong dan dedak padi. Perlakuan disusun dengan pola rancangan acak lengkap yang terdiri dari dedak padi tanpa inokulum (RBo), dedak padi dengan inokulum (RBi), tepung singkong tanpa inokulum (CFo), dan tepung singkong dengan inokulum (CFi). Media tumbuh difortifikasi dengan larutan mineral yang mengandung $\mathrm{Cu}$ (100 ppm), Mn (100 ppm), Zn (100 ppm), I (10 ppm), Fe (2.5 ppm) dan Co (2 ppm). Perlakuan inokulasi $S$. cerevisiae dapat mengurangi kontaminasi jamur. Sifat fisik tepung singkong memiliki aroma dan tekstur yang lebih baik daripada dedak padi yang cenderung beraroma tengik. Komposisi nutrien pada substrat tepung singkong dan dedak padi cenderung sama, namun kandungan protein kasar dalam dedak padi cenderung lebih tinggi setelah fermentasi. Kandungan mineral ( $\mathrm{Zn}$ dan $\mathrm{Fe}$ ) relatif menurun pada substrat dedak padi sebagai dengan inokulum dibandingkan substrat dari tepung singkong. Dapat disimpulkan bahwa inkorporasi mikromineral pada subsrat tepung singkong dengan inokulasi $S$. cerevisiae lebih baik dari dedak padi.
\end{abstract}

Keywords: Mineral organik, tepung singkong, $S$. cerevisiae, dedak padi, ternak ruminansia 


\section{INTRODUCTION}

Livestock organically based development has been concerned in the recent decades. Due to it is not only support to ecological balance and animal welfare but also need to generate organic product for human better life. The use of organic feed additive increase nutrient utilization and minimize environmental contamination. Organic mineral supplementation had an important role in growth performance, nutrient utilization, trace mineral balance and serum mineral concentration. Lower dose of organic mineral showed the similar result as inorganic mineral with required amount therefore it reduced excretion as inorganic element and reduced soil or environmental toxicity ${ }^{(1)}$.

Mineral bioavailability is defined as the ingested nutrient fraction that is absorbed and subsequently utilized for normal physiological functions of human or animal $^{(2)}$. In order to increase its bioavailability, inorganic mineral could be incorporated with organic compound which formed organic mineral complexes or chelated mineral. Chelated mineral with the peptide compound is potential to prevent mineral deficiencies ${ }^{(3)}$.

Substrates for yeast growth that was fortified by some minerals potentially absorbed into yeast cells. Addition of $\mathrm{Zn}^{2+}$ into medium supported the mycelia yeast growth. It would be associated with mineral incorporated by either cells or organic substances in the cells made chelated minerals $^{(4)}$. Micromineral supplementation in organic form was improving broiler performance $^{(5)}$, feed digestibility ${ }^{(6)}$, health and reproductive performance of ruminant $^{(7)}$.

Moreover, Saccharomyces cerevisiae is one of yeast species was wildly used for food and feed fermentation. S. cerevisiae was reported inhibited aflatoxin contamination in broiler feed ${ }^{(8)}$ and reduced anti-nutrition factor (phytic acids) in soybeanmeal $^{(9)}$. In ruminant addition of $S$. cerevisiae on feed could lead to increase the milk production of dairy $\operatorname{cow}^{(10)}$ and stabilize ruminal $\mathrm{pH}$ that preventing sub acute ruminal acidocis ${ }^{(11)}$. However, organic mineral consisted of some microminerals involving yeast which was cultured on local feedstuff still limited reported. This research was conducted to evaluate physical and chemical properties of ruminant organic mineral additive for ruminant incorporated by $S$. cerevisiae cultivated on different growth media consisted of cassava flour and rice bran, respectively. The result of the experiment to contribute animal production sustainability based on local feed sources.

\section{MATERIALS AND METHODS}

Organic mineral was prepared involving fermentation processes by inoculation of Saccharomyces cerevisiae ATCC 9763. Substrates were used as yeast medium growth consisted of rice bran (Oryza sativa) or cassava flour meal (Manihot sp). Prior to inoculation, yeast was precultured on malt extract broth $\left(\right.$ Oxoid $\left.^{\circledR}\right)$ which was incubated during 48 hours then $S$. cerevisiae $(5 \% \quad \mathrm{v} / \mathrm{w})$ inoculated into substrates. Substrates were fortified with microminerals contained of $\mathrm{Cu}$ (100 ppm), Mn (100 ppm), Zn (100 ppm), I (10 ppm), Fe (2.5 ppm) and Co (2 ppm). Formulation per $\mathrm{kg}$ substrate consisted of $\mathrm{CuSO}_{4} .5 \mathrm{H}_{2} \mathrm{O} \quad(9.810 \mathrm{~g})$, $\mathrm{MnCl}_{2} .4 \mathrm{H}_{2} \mathrm{O} \quad(7.129 \mathrm{~g}), \quad \mathrm{ZnSO}_{4} .7 \mathrm{H}_{2} \mathrm{O}$ $(12.646 \mathrm{~g}), \quad \mathrm{KI}(0.217 \mathrm{~g}), \mathrm{FeCl}_{2} .4 \mathrm{H}_{2} \mathrm{O}$ $(0.177 \mathrm{~g})$ and $\mathrm{CoCl}_{2} \cdot 6 \mathrm{H}_{2} \mathrm{O}(0.192 \mathrm{~g})$. Minerals were diluted with sterilized distilled water and added into substrate into moisture content about $40 \%$. Mixture consisted of mineral and substrate was according to the treatment. Incubation was 
conducted in room temperature $\left(25-30^{\circ} \mathrm{C}\right)$ and facultative condition.

Organic mineral was harvested on 7 days of facultative fermentation then dried in oven at $55^{\circ} \mathrm{C}$ (up to $24-48 \mathrm{~h}, \mathrm{DM} 10 \%$ ), followed by ground and sieved to pass a 1 $\mathrm{mm}$ of particle size. Chemical analysis of sample consisted of dry matter, organic matter, crude protein, crude fibre was conducted according to AOAC methods ${ }^{(12)}$ and content of ether extract and nitrogen free extract was calculated by difference in dry matter basis. Sample was prepared in dry condition to prevent deterioration and fungal contamination. The concentration of trace elements was measured by atomic absorption spectrophotometer ${ }^{(5)}$.

The experiment was arranged on completely randomized design with 4 treatments and 3 replications. Treatment consisted of rice bran without inoculants ( $\mathrm{RBo})$, rice bran with inoculants ( $\mathrm{RBi})$, cassava flour without inoculants (CFo), cassava flour with inoculants $(\mathrm{CFi})$. Data from physical properties were analyzed descriptively and data from chemical properties were analyzed using analysis of variance (ANOVA). In order to compare between treatments mean, data were statistically analysed with Duncan Multiple
Range Test using Co-STAT ${ }^{\circledR}$ Statistical Software (Cohort 2008) ${ }^{(13)}$. Analysis of interrelationship parameters was performed by hierarchical clustering analysis/ $\mathrm{HCA}^{(14)}$. Visualization of HCA was analyzed using the dendogram-heatmap that constructed using 'heatmap. 2 ' function from 'gplots library in the R-statistical software ${ }^{(15)}$. Pretreatment of data were calculated based on the relative differential data from treatments and control according the formula $\left(x_{\mathrm{t}} / x_{\mathrm{0}}-1\right)$ where $x_{o}$ and $x_{t}$ denote before and after fermentation data respectively.

\section{RESULTS AND DISCUSSION}

Evaluation of physical characteristics of organic mineral incorporated by $S$. cerevisiae (MEY) on different growth media was performed at the 7 days of incubation in facultative condition. Sample was treated by inoculation of yeast seemed to be better in sensory test in accordance with odour, texture and occurring fungal contamination (Table 1). Then, chemical composition of MEY showed that no difference in all parameters except for crude fibre and nitrogen free extract + ether extract (Table 2).

Table 1. Physical characteristics and fungal contamination of organic mineral incorporated by $S$. cerevisiae on different growth substrates

\begin{tabular}{lllll}
\hline $\begin{array}{l}\text { Observed } \\
\text { Variables }\end{array}$ & RBo & RBi & CFo & CFi \\
\hline $\begin{array}{l}\text { Texture after } \\
\text { harvesting }\end{array}$ & Agglomerated & Agglomerated & Agglomerated & Granulated \\
\hline Odor & Rancid & Poor & Poor & Good \\
\hline $\begin{array}{l}\text { Fungal } \\
\text { Contamination }\end{array}$ & Contaminated & Low-Contaminated & Contaminated & No-Contaminated \\
\hline
\end{tabular}

Visualization
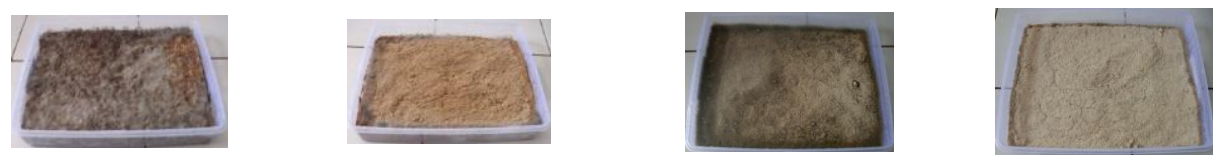

RBo: rice bran without inoculation, $R B$ i: rice bran inoculated by $S$. cerevisiae, CFo: cassava flour without inoculation, CFi: cassava flour inoculated by $S$. cerevisiae. 
Both substrates were fermented without yeast inoculation showed the contamination by fungi that was indicating not only visualized texture but also not good odour (off-flavour). Although substrates were sterilized before inoculation, fungal contamination might be occurred while oxygen presence in the facultative fermentation system. Moreover, rancidity was observed in rice bran that it could be associated with oxidative mechanism. Due to oxygen is possibly presence in the facultative fermentation and implied stimulation of lipolitic enzyme activity. Fatty acid in rice bran is readily oxidized by lipolitic enzymes such as lipase and lipoxgenase ${ }^{(16)}$.

As a substrate for yeast growth, cassava reflected better physical traits with fungal contamination lower contamination. S. cerevisiae was grown on medium would compete and prevent other microbes to contaminate the substrates. S. cerevisiae could be used as microbial agent to minimize Aspergillus flavus contamination in animal feed ${ }^{(8)}$. Growth of $S$. cerevisiae seems favourably while substrate is readily available supplied from glucose ${ }^{(17)}$. Due to starch (complexes form of glucose) contained in cassava flour was higher than rice bran ${ }^{(18)}$.

Some chemical parameters were changed after fermentation consisted of crude protein $(\mathrm{CP})$, crude fibre $(\mathrm{CF})$, ether extract $(\mathrm{EE})+$ nitrogen free extract $(\mathrm{NFE})$, ash whereas organic matter $(\mathrm{OM})$ and dry matter showed not changeable (Figure 1). Characteristic of parameters change could be analysed using hierarchical cluster which was indicate similarities in each substrates. $\mathrm{DM}$ change was closely related to $\mathrm{OM}$ compared from NFE+EE. CP and CF had higher similarity compared from the interrelationship with other parameters (ash and EE).

Addition of yeast for incorporating microminerals was relatively increase value of $\mathrm{CF}, \mathrm{CP}$ and ash when NFE+EE reduced. In this experiment, NFE+EE in cassava were observed higher than rice bran. Moreover, lipid content (EE) in cassava $(0.7 \%)$ was lower than in rice bran $(14.1 \%)^{(18)}$. Reducing starch and lipid caused by activity of $S$. cerevisiae secrete enzymes consisting $\alpha$-amylase for degrading glucose/starch then lipase for degrading lipid ${ }^{(19)}$ instead of protease enzyme. Organic matter of feedstuffs could be fractioned into structural (starch) and non-structural (crude fiber) carbohydrate. In term, NFE is non-structural carbohydrate that easily enzymatic degradation than crude fiber ${ }^{(20)}$. Consequently, some nutrients ( $\mathrm{CF}$ and $\mathrm{CP}$ ) which were not degraded by $S$. cerevisiae increased relatively while the other nutrients (NFE+EE) decreased.

Table 2. Nutrient composition of microminerals incorporated by S. cerevisiae on different growth substrates

\begin{tabular}{|c|c|c|c|c|c|c|c|c|c|c|c|c|}
\hline Parameters & \multicolumn{3}{|c|}{ RBo } & \multicolumn{3}{|c|}{$\mathbf{R B i}$} & \multicolumn{3}{|c|}{ CFo } & \multicolumn{3}{|c|}{ CFi } \\
\hline DM (\%) & $85.7^{\mathrm{a}}$ & \pm & 5.0 & $85.9^{\mathrm{a}}$ & \pm & 2.6 & $79.4^{\mathrm{a}}$ & \pm & 3.2 & $84.8^{\mathrm{a}}$ & \pm & 4.0 \\
\hline $\mathrm{OM}$ & $81.6^{\mathrm{b}}$ & \pm & 0.7 & $82.4^{b}$ & \pm & 1.0 & $98.3^{\mathrm{a}}$ & \pm & 0.1 & $98.5^{\mathrm{a}}$ & \pm & 0.1 \\
\hline Ash (\%DM) & $18.4^{\mathrm{a}}$ & \pm & 0.7 & $17.6^{\mathrm{a}}$ & \pm & 1.0 & $1.7^{\mathrm{b}}$ & \pm & 0.1 & $1.5^{\mathrm{a}}$ & \pm & 0.1 \\
\hline $\mathrm{CP}(\% \mathrm{DM})$ & $12.1^{\mathrm{a}}$ & \pm & 1.2 & $13.2^{\mathrm{a}}$ & \pm & 1.9 & $3.3^{\mathrm{b}}$ & \pm & 1.3 & $3.4^{\mathrm{b}}$ & \pm & 1.2 \\
\hline $\mathrm{CF}(\% \mathrm{DM})$ & $37.0^{\mathrm{b}}$ & \pm & 5.0 & $43.5^{\mathrm{a}}$ & \pm & 1.0 & $12.9^{\mathrm{c}}$ & \pm & 3.8 & $16.7^{\mathrm{c}}$ & \pm & 0.6 \\
\hline $\mathrm{NFE}+\mathrm{EE}(\% \mathrm{DM})$ & $32.5^{\mathrm{b}}$ & \pm & 6.9 & $25.7^{\mathrm{b}}$ & \pm & 2.4 & $82.1^{\mathrm{a}}$ & \pm & 4.6 & $78.5^{\mathrm{a}}$ & \pm & 0.8 \\
\hline
\end{tabular}

DM: $\quad$ Dry Matter, CP: Crude Protein, CF: Crude Fibre, NFE: Nitrogen Free Extract, RBo: rice bran without inoculation, $\mathrm{RBi}$ : rice bran inoculated by $S$. cerevisiae, CFo: cassava flour without inoculation, CFi: cassava flour inoculated by $S$. cerevisiae. 

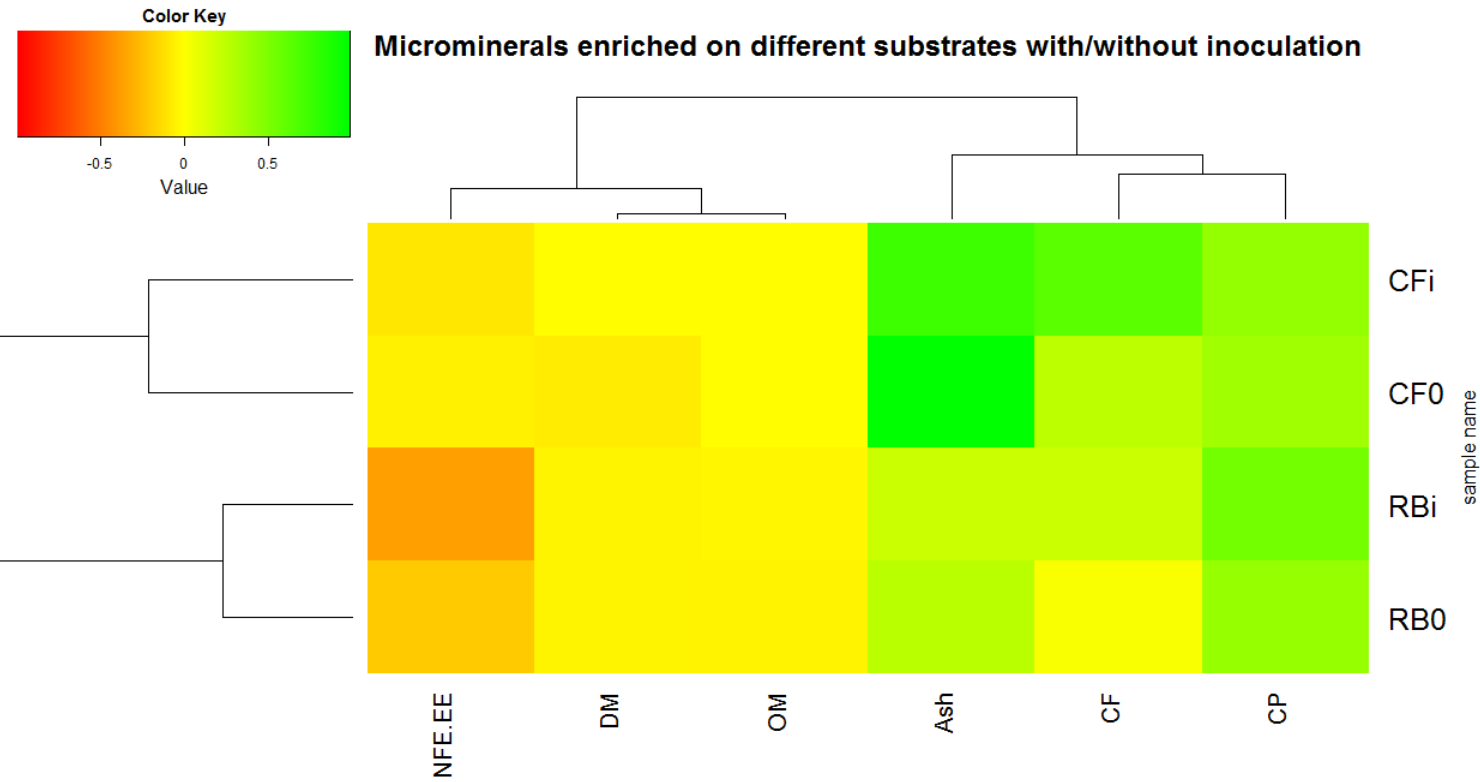

Figure 1. Hierarchical clustering analysis of nutrient composition change during fermentation. (Colour key consisted of green, yellow and red denote respectively for value of increase, no change, and decrease fold)

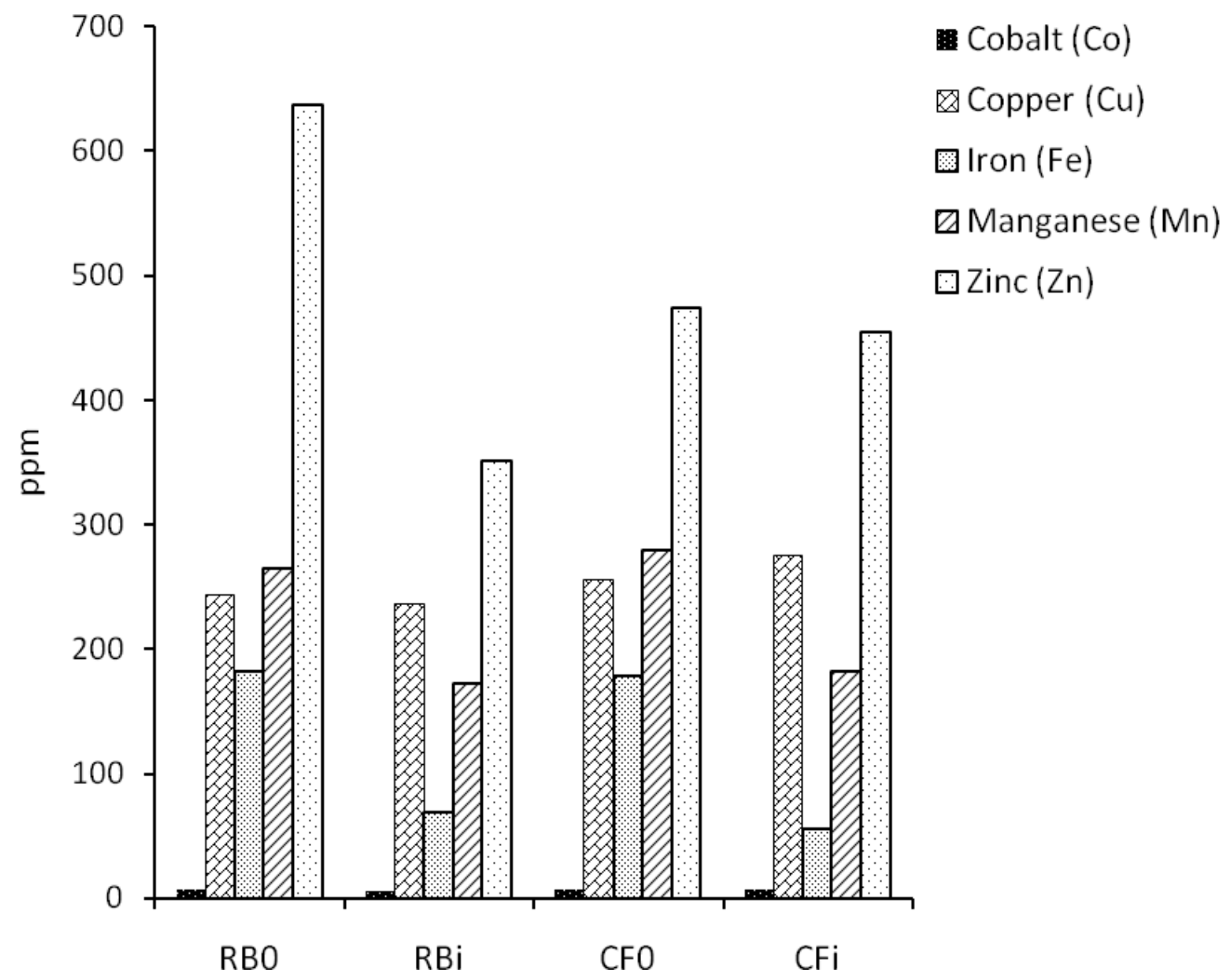

Figure 2. Micro-minerals content incorporated by S. cerevisiae on different substrates (RBo: rice bran without inoculation, RBi: rice bran inoculated by $S$. cerevisiae, CFo: cassava flour without inoculation, CFi: cassava flour inoculated by S. cerevisiae) 
During the growth activity, S. cerevisiae metabolize NFE as sugar sources (17) and secreted lypolitic enzyme to metabolize lipid $(\mathrm{EE})^{(21)}$ to generate energy for maintenance and to produce secondary metabolites. Yeast fermented the substrate consisting of microminerals that could be incorporated into organic form (chelated minerals) and improved flavour of fortified substrate. S. cerevisiae had been widely used as bio-flavour producers to ferment sugar and generate volatile compound (e.g. $\beta$-pinene, $\beta$-terpineol, and D-limonene etc.) as flavour components ${ }^{(22) \text {. }}$

After fermentation, microminerals (i.e. $\mathrm{Zn}$ and $\mathrm{Fe}$ ) content in both substrates showed reduced in inoculation treatments (Figure 2). It related to the mineral utilization to support yeast activity. Other minerals (i.e. $\mathrm{Co}, \mathrm{Mn}, \mathrm{Cu}$ ) seem similar with and without yeast inoculation. Incorporating inorganic microminerals into organic form might be involved by mechanism that mineral ions (i.e. $\mathrm{Fe}^{2+}$, $\mathrm{Zn}^{2+}, \mathrm{Mn}^{2+}, \mathrm{Cu}^{2+} \mathrm{Co}^{2+}$ and $\left.\mathrm{I}^{-}\right)$had a chance to bind organic compound as metabolic product or entry into yeast cells. This mechanism was supported that yeast Aureobasidium pullulans had capable to uptake $\mathrm{Zn}^{2+}$ and incorporated with mycelia cells ${ }^{4}$. Furthermore, $S$. cerevisiae supports binding system between $\mathrm{Fe}$ and organic compound such as amino acids, e.g. histidine, lysine and arginine ${ }^{(23)}$.

Although addition of yeast in substrate fermentation tended to similar, inoculation of $S$. cerevisiae had beneficial for reducing anti-nutrient compound in substrate. Phytase enzyme degrades mineral complex-P (phosphorus) with phytic acid into myo-inositol phosphate, myo-inositol and inorganic phosphate ${ }^{9}$ and increases availability in digestion system for animals. Therefore, supplementation of organic microminerals or chelated minerals could support animal productivity and health status $^{(5,24,25)}$.

\section{CONCLUSION}

Organic microminerals additive was incorporated by $S$. cerevisiae cultivated on cassava flour had better than rice bran in physical characteristic. However, composition of microminerals tended to similar in both substrates with or without inoculation. The further research need to be conducted to evaluate chelating mechanism involving yeast activity and influence of organic mineral on animal productivity.

\section{ACKNOWLEDMENT}

The authors would like to gratefully appreciate to the Indonesian Institute of Sciences (LIPI) through the Thematic Feed Additive Research Project (FY 2012) for supporting the experiment.

\section{REFERENCES}

1. S. Mondal, S.K. Paul, B. Bairagi, M.C. Pakhira and P. Biswas. Comparative studies of reducing level of organic with inorganic trace minerals supplementation on the performance, nutrient digestibility and mineral balance in cross-bred male calves. Volume 20, Article \#112 (2008). http://www.lrrd.org/lrrd20/7/mond2011 2.htm. Retrieved on June 22, 2013.

2. S. Fairweather-Tait, R.F. Hurrell. Bioavailability of minerals and trace elements. Nutr. Res. Rev. 9: 295-324 (1996).

3. L. Guo, P.A. Harnedy, B. Li, H. Hou, Z. Zhang, X. Zhao, R.J. FitzGerald. Food protein-derived chelating peptides: biofunctional ingredients for dietary mineral bioavailability enhancement. Trends in Food Sci. Technol. 37: 92-105 (2014). 
4. N. Krogh, J. Olsen, B. Jensen, M. Reeslev. Uptake of $\mathrm{Zn}^{2+}$ by yeast and mycelial growth form of Aureobasidium pullulans grown in chemostat culture. FEMS Microbiol. Lett. 163: 249-253 (1998).

5. A.K. Singh, T.K. Ghosh, S. Haldar. Effects of methionine chelate-or yeast proteinate-based supplement of copper, iron, manganese and zinc on broiler growth performance, their distribution in the tibia and excretion into the environment. Biol. Trace Element Res. 164: 253-260 (2015).

6. M. Briens, Y. Mercier, F. Rouffineau, V. Vacchina, P.A. Geraert. Comparative study of a new organic selenium source vs. seleno-yeast and mineral selenium sources on muscle selenium enrichment and selenium digestibility in broiler chickens. British J. Nutr. 110: 617-624 (2013).

7. A. Formigoni, M. Fustini, L. Archetti, S. Emanuele, C. Sniffen, G. Biagi. Effects of an organic source of copper, manganese and zinc on dairy cattle productive performance, health status and fertility. Anim. Feed Sci. Technol. 164: 191-198 (2011).

8. E. Kusumaningtyas, R. Widiastuti, R. Maryam. Reduction of aflatoxin B1 in chicken feed by using Saccharomyces cerevisiae, Rhizopus oligosporus and their combination. Mycopathol. 162: 307-311 (2006).

9. K.W. Tudor, M.A. Jones, S.R. Hughes, J.P. Holt, B.R. Wiegand. Effect of fermentation with Saccharomyces cerevisiae strain PJ69-4 on the phytic acid, raffinose, and stachyose contents of soybean meal. Prof. Anim. Sci. 29: 529-534 (2013).

10. R.G.S.Bruno, H.M. Rutigliano, R.L. Cerri, P.H. Robinson, J.E.P. Santos. Effect of feeding Saccharomyces cerevisiae on performance of dairy cows during summer heat stress. Anim.
Feed Sci. Technol. 150: 175-186 (2009).

11. M. Thrune, A. Bach, M. Ruiz-Moreno, M.D. Stern, J.G. Linn. Effects of Saccharomyces cerevisiae on ruminal $\mathrm{pH}$ and microbial fermentation in dairy cows: yeast supplementation on rumen fermentation. Livestock Sci. 124: 261265 (2009) .

12. Association of Official Analytical Chemist [AOAC]. Official Methods of Analysis, AOAC International. $19^{\text {th }} \mathrm{Ed}$., Association of Official Analytical Chemist, Washington DC., USA. (2012).

13. Cohort. CoSTAT Version 6.400. Copyright 1998-2008. Cohort Software. 798. Lighthouse Ave, Montere, CA. 93940. USA (2008).

14. E.E. Waddell, J.L. Frisch-Daiello, M.R. Williams, M.E. Sigman, Hierarchical cluster analysis of ignitable liquids based on the total ion spectrum. $J$. Forensic. Sci. 59: 1198-1204 (2014).

15. $\mathrm{R}$ Core Team. R: A language and environment for statistical computing. $\mathrm{R}$ Foundation for Statistical Computing, Vienna, Austria (2013).

16. SM. Kim, H.J. Chung, S.T. Lim. Effect of various heat treatments on rancidity and some bioactive compounds of rice bran. J. Cereal Sci. 60: 243-248. (2014).

17. M. Hanscho, D.E. Ruckerbauer, N. Chauhan, H.F. Hofbauer, S. Krahulec, B. Nidetzky, S.D. Kohlwein, J. Zanghellini, K. Natter. Nutritional requirements of the $\mathrm{BY}$ series of Saccharomyces cerevisiae strains for optimum growth. FEMS Yeast Res. 12: 796-808 (2012).

18. H. Hartadi, S.Reksohadiprodjo, A.D. Tillman, Tabel Komposisi Pakan untuk Indonesia. Gadjah Mada University Press, 2005. 
19. M.H. Lim, O.H. Lee, J.E. Chin, H.M. Ko, I.C. Kim, H.B. Lee, S.Y. Im, S. Bai, Simultaneous degradation of phytic acid and starch by an industrial strain of Saccharomyces cerevisiae producing phytase and $\alpha$-amylase. Biotechnol. Lett. 30: 2125-2130. (2008).

20. S. Uttam, S. Leticia, H. Dennis, H. Nicholas, S. Lawton, H. Gary, E.K. David. Common terms used in animal feeding and nutrition. The University of Georgia Cooperative Ext. Bull. 1367: 119 (2013).

21. B. Ploier, Scharwey, M., Koch, B., Schmidt, C., Schatte, J., Rechberger, G., Kollroser, M., Hermetter A, Daum, G. Screening for hydrolytic enzymes reveals Ayrlp as a novel triacylglycerol lipase in Saccharomyces cerevisiae. J. Biol. Chem. 288: 36061-36072 (2013)

22. S. Lalou, F. Mantzouridou, A. Paraskevopoulou, B. Bugarski, S. Levic, V. Nedovic. Bioflavour production from orange peel hydrolysate using immobilized Saccharomyces cerevisiae. Appl. Microbial. Biotechnol. 97: 9397-9407 (2013).

23. L. de la Hoz, A.N. Ponezi, R. F. Milani, V.S.N. da Silva, A.S. de Souza, M.T. Bertoldo-Pacheco. Iron-binding properties of sugar cane yeast peptides. Food Chem. 142: 166-169 (2014).

24. K. Karkoodi, M. Chamani, M. Beheshti, S.S. Mirghaffari, A. Azarfar. Effect of organic zinc, manganese, copper, and selenium chelates on colostrum production and reproductive and lameness indices in adequately supplemented Holstein cows. Biol. Trace Elem. Res. 146: $42-46$ (2012).

25. J.C. Peters, D.C. Mahan, T.G. Wiseman, N.D. Fastinger. Effect of dietary organic and inorganic micromineral source and level on sow body, liver, colostrum, mature milk, and progeny mineral compositions over six parities. J Anim. Sci. 88: 626-637 (2010). 